\title{
CUTANEOUS BASOPHIL HYPERSENSITIVITY REACTION TO PHYTOHEMAGGLUTININ IN REPEAT BREEDER COWS
}

\author{
LAZAREVIĆ M*, MILOVANOVIĆ A**, MILANOVIĆ SVETLANA*, KIROVSKI DANIJELA* and ILIĆ V* \\ * Faculty of Veterinary Medicine, Belgrade, ** Scientific Veterinary Institute, Novi Sad
}

(Received 8. June 2004)

In this study the relationship was explored between general immune reactivity, as estimated by the cutaneous basophil hypersensitivity reaction (CBHR) to phytohemagglutinin (PHA), and the level of anti-sperm antibodies of the Ig A and Ig G class in the cervical mucus and sera of cows with different reproductive results. The hypersensitivity test was performed on the day of artificial insemination when cervical mucus and sera samples were also collected. The animals were divided into groups according to the total number of inseminations, number of inseminations per calving and their age. The titer of antibodies was determined by the indirect immunofluorescence method using sperm cells suspended in Tris egg-yolk extender.

Our results indicate that the intensity of CBHR is lowest in cows inseminated once or twice and in younger animals, while, there were no differences between the groups when they were formed according to the number of inseminations per calving. Titers of antisperm antibodies (ASA) of the Ig A class in cervical mucus (CM) increased with the number of artificial inseminations, number of inseminations per calving and age of the cows.

Key words: PHA, cows, subfertility, Ig A, Ig, cervical mucus, sera, sperm cells

\section{INTRODUCTION}

Repeat breeding (RB) is still a significant problem in the reproduction of dairy cows. It is usually defined as a lack of conception following three subsequent artificial inseminations (Al) with no obvious symptoms of genital tract disease. A repeat-breeder is a cow which shows a reduced probability of conception, while all other factors are optimal (Casida, 1961), and thus requires more Al attempts to achieve pregnancy. If mated naturally, RB cows or heifers very often show improved reproductive results (Vukotić et al., 1982). The possible causes of this phenomenon are numerous and include delicate nutritional misbalance, subtle hormonal disturbances and immunological alterations. It was postulated that enhanced immunological reactivity to sperm or semen extender antigens might be one of the reasons for RB (Park and Hunter, 1977). 
In natural mating, an immune response to sperm antigens usually does not occur due to the low sperm and seminal plasma immunogenicity (Hogarth, 1982). Also, all body fluids important for fertilization (seminal plasma, cervical mucus, follicular and uterine fluid) have immunosuppressive properties (Landers et al., 1994). In Al the chances for immunization of females to sperm antigens are enhanced because seminal plasma is diluted several times, thus reducing its very strong immunosuppressive effects (Lazarević, 1991; Lazarević et al., 1992) and new antigens originating from semen extenders are present. We have documented (Lazarević et al,. 2003; Jaćević and Lazarević, 2000; Jaćević, 1998) by sperm agglutination and the indirect immunofluorescence method that bull spermatozoa differ in antigenicity if different semen extenders are used for semen preparation for Al. Therefore, it was possible to postulate that cows with high general immunoreactivity (high responders) might also react to sperm and extender antigens and become repeat breeders.

One of the methods that is widely used in veterinary medicine to examine general immunological reactivity is the cutaneous basophil hypersensitivity reaction to phytohemagglutinin (PHA). PHA is a herbal lectin with mitogenic properties and usually serves in laboratory practice to induce nonspecific proliferation of mononuclear cells (Ekkel et al., 1995). If administered intradermally, PHA provokes a hypersensitive reaction characterized by enhanced skin thickness, erythema, induration and swelling accompanied with mononuclear cell accumulation. Histological examination of the skin at the site of PHA injection reveals massive accumulation of basophil cells and therefore this phenomenon was described as the cutaneous basophil hypersensitivity reaction or, alternatively, the PHA skin test. Moreover, PHA leads to changes in permeability of high endothelial venules, enabling easier passage of lymphocytes in tissues (Stedecker et al., 1977). The same authors postulated that the CBHR is a consequence of lymphokine production by stimulated mononuclear cells. The degree of reaction is highest $24 \mathrm{hrs}$ after application (Mc Corkie et al., 1980) This test has been used to investigate the influence of various stress factors on the immune response in various domestic animals (Ekkel et al., 1995; Wesley and Kelly, 1984; Kelley et al., 1982; Regnier and Kelley, 1981; Žikić, 2000; Lazarević et al., 2000). It was clearly documented that under intensive stress conditions the $\mathrm{CBH}$ reaction is significantly reduced. The PHA skin test is frequently used as an indicator of in vivo cellular immunity in calves (Kelley et al., 1982).

\section{MATERIAL AND METHODS}

Cutaneous basophil hypersensitivity reaction (CBHR): A total of 60 Holstein cows was tested by intradermal application of $200 \mu \mathrm{g}$ of PHA (INEP, Zemun). PHA was diluted in sterile phosphate buffered saline (PBS) $\mathrm{pH}$ 7.2, to reach a final concentration of $1 \mathrm{mg} / \mathrm{mL}$ and $200 \mu \mathrm{L}$ of this solution was intradermally injected into the neck region. As a control, the same volume of sterile PBS was injected at a $15 \mathrm{~cm}$ distant site. Skin thickness (ST) was measured by cutimeter prior to administration of PHA or PBS and 24 hrs later. The magnitude of the reaction was 
calculated as the difference in double-fold skin thickness between the sites of PHA and PBS application according to the following formulas:

$$
\begin{aligned}
& \Delta \mathrm{PHA}=\mathrm{ST} 0^{\mathrm{h}}-\mathrm{ST} 24^{\mathrm{h}} \\
& \Delta \mathrm{PBS}=\mathrm{ST} 0^{\mathrm{h}}-\mathrm{ST} 24^{\mathrm{h}} \\
& \mathrm{CBHR}=\Delta \mathrm{PHA}-\Delta \mathrm{PBS}
\end{aligned}
$$

Basically, animals were divided into four groups according to the total number of previous artificial inseminations as follows: cows and heifers inseminated 1-2 times, cows inseminated 3-5, 6-8 and over 8 times. Furthermore, the results obtained were analysed considering the number of inseminations per calving and also the age of the cows. All cows were inseminated with bull semen prepared for Al with Tris egg-yolk extender.

Cervical mucus sampling: Prior to Al, CM samples were collected by placing a sterile sponge swab in the near vicinity of the external cervix portion as described earlier (Lazarević et al, 2003). All samples were kept frozen at - $20^{\circ} \mathrm{C}$ until use.

Semen sampling: Semen samples were collected from four black and white spotted bulls (Holstein breed) by means of an artificial vagina in the Regional Center for Artificial Insemination. The semen possessed normal characteristics of motility, morphology and concentration and underwent the standard procedure of preparation for Al. Ejaculates were diluted with Tris egg yolk extender at an average ratio of $1: 10$ and frozen at $-196{ }^{\circ} \mathrm{C}$ until requred.

Indirect immunofluorescence assay (IIF): The IIF assay was performed according to Noel et al. (1974) as described in detail earlier (Lazarević et al., 2003). Briefly, after thawing the 12 (3 from each of 4 bulls) medium French straws for Al, sperm cells were washed twice in PBS ( $\mathrm{pH} 7.2)$, resuspended by Vortex and used for smear preparations. On the dried sperm cell smears, $10 \mu \mathrm{l}$ of $\mathrm{CM}$ sample (inactivated at $56^{\circ} \mathrm{C}$ for 20 minutes) was placed and incubated for $20 \mathrm{~min}$ at $37^{\circ} \mathrm{C}$ in a wet chamber. Following incubation, the slides were washed three times (5 $\min$ ) in PBS and dried at room temperature. In the second step, $10 \mu$ l of secondary FITC (fluorescein isothiocyanate) conjugated antibodies (anti-bovine Ig A, ICN, USA, Cat No 641 751) was placed on the slide and incubated again under the same conditions. Anti Ig A antibodies were conjugated with FITC (ICN, USA, Cat No F 4274) according to The and Feltkamp (1970). After incubation, followed by the same washing procedure, the slides were kept in the dark and wet chamber till examined. As a positive control we used sera obtained from calves after immunization with the contents of straws prepared with Tris egg yolk extender as described in detail elsewhere (Lazarevic et al., 2000). Calf sera obtained before immunization served as the negative control. Using a NIKON EFD - 3 microscope with the B-2A filter at $1600 \mathrm{X}$ magnification, the appearance of fluorescence on the head, tail or neck of the sperm cell was considered as a positive result and the last dilution giving a positive reaction was taken into account. Titer values were expressed according to Sjurin et al. (1984) as $\log _{2} \mathrm{n}(1: 2=1,1: 4=2$ etc). 
Statistical analyses were performed after calculating mean values and standard deviations. The significance of the differences between mean values was estimated by Student's t test.

\section{RESULTS}

Our results indicated differences in the degree of cutaneous basophil reaction to PHA (CBHR) in cows with different total numbers of artificial inseminations (Table 1). These differences were statistically significant when CBHR results obtained on the animals inseminated 1-2 and 6-8 times were compared. We found the same level of significance when we compared the results obtained for the animals inseminated 1-2 and over 8 times (Table 1a).

Table 1. CBHR in cows with different numbers of artificial inseminations $(\bar{X} \pm S D)$

\begin{tabular}{|c|r|c|}
\hline Total number of AI & $\mathrm{N}$ & CBHR $(\mathrm{mm})$ \\
\hline \hline $1-2$ & 9 & $3.74 \pm 2.148$ \\
\hline $3-5$ & 12 & $6.06 \pm 3.048$ \\
\hline $6-8$ & 9 & $6.19 \pm 1.861$ \\
\hline over 8 & 30 & $7.54 \pm 3.145$ \\
\hline
\end{tabular}

Table 1a. Statistical significance of differences in $\mathrm{CBH}$ reaction values between cows with different numbers of artificial inseminations

\begin{tabular}{|c|c|c|c|c|}
\hline Total number of Al & $1-2$ & $3-5$ & $6-8$ & over 8 \\
\hline \hline $1-2$ & - & NS & $\mathrm{P}<0.05$ & $\mathrm{P}<0.05$ \\
\hline $3-5$ & - & - & NS & NS \\
\hline $6-8$ & - & - & - & NS \\
\hline
\end{tabular}

NS - not significant

When we sorted the results obtained for CBHR on the same 60 cows, according to the number of Al needed for successful pregnancy we found no statistical differences between the experimental groups (Tables 2, 2a).

Table 2. CBHR in cows with different numbers of artificial inseminations per calving $(\overline{\mathrm{X}} \pm \mathrm{SD})$

\begin{tabular}{|c|c|c|}
\hline Number of Al per calving & N & CBHR $(\mathrm{mm})$ \\
\hline \hline $1-2$ & 24 & $6.22 \pm 4.810$ \\
\hline $3-6$ & 23 & $5.10 \pm 2.505$ \\
\hline over 6 & 13 & $6.25 \pm 2.135$ \\
\hline
\end{tabular}


Acta Veterinaria (Beograd), Vol. 54, No. 5-6, 337-346, 2004.

Lazarević $\mathrm{M}$ et al. Cutaneous basophil hypersensitivity reaction to phytohemagglutinin in repeat breeder cows

Table 2a. Statistical significance of differences in $\mathrm{CBH}$ reaction values between cows with different numbers of artificial inseminations per calving

\begin{tabular}{|c|c|c|c|}
\hline Number of Al per calving & $1-3$ & $3-6$ & over 6 \\
\hline \hline $1-2$ & - & NS & NS \\
\hline $3-6$ & - & - & NS \\
\hline
\end{tabular}

NS - not significant

Finally, all cows included in this study were divided into three groups according to their age. It was documented that the younger animals (up to three years of age) had the lowest CBHR (Table 3) but we found no statistically significant differences between animals aged 3-5 and those older than 5 years (Table 3a).

Table 3. CBHR in cows of different age

\begin{tabular}{|c|c|c|}
\hline Age (years) & $\mathrm{N}$ & CBHR $(\mathrm{mm})$ \\
\hline \hline up to 3 & 15 & $3.12 \pm 1.820$ \\
\hline $3-5$ & 15 & $6.54 \pm 1.770$ \\
\hline over 5 & 30 & $6.86 \pm 2.545$ \\
\hline
\end{tabular}

Table 3a. Statistical significance of differences in CBHR between cows of different age

\begin{tabular}{|c|c|c|c|}
\hline Age (years) & up to 3 & $3-5$ & over 5 \\
\hline \hline up to 3 & - & $\mathrm{p}<0.01$ & $\mathrm{p}<0.01$ \\
\hline $3-5$ & - & - & NS \\
\hline
\end{tabular}

NS - not significant

The titer of Ig A anti-sperm antibodies in the cervical mucus of cows with different numbers of $\mathrm{Al}$ are presented in Table 4. The lowest values were recorded in cows with 1-2 artificial inseminations and the highest in cows inseminated more than 8 times. Statistically significant differences were found only when titer values in cows inseminated 1-2 times were compared to those for the other groups (Table 4a).

Table 4. Titer of Ig A anti-sperm antibodies in cervical mucus of cows with different numbers of artificial inseminations $(\bar{X} \pm S D)$

\begin{tabular}{|c|c|c|}
\hline Total number of $\mathrm{Al}$ & $\mathrm{N}$ & Titer of CM anti-sperm Ig A \\
\hline \hline $1-2$ & 9 & $4.21 \pm 0.782$ \\
\hline $3-5$ & 112 & $6.76 \pm 2.386$ \\
\hline $6-8$ & 9 & $6.65 \pm 1.509$ \\
\hline over 8 & 30 & $7.10 \pm 2.259$ \\
\hline
\end{tabular}


Table 4a. Statistical significance of differences in CM anti-sperm Ig A titer between cows with different number of artificial inseminations

\begin{tabular}{|c|c|c|c|c|}
\hline Total number of Al & $1-2$ & $3-5$ & $6-8$ & over 8 \\
\hline \hline $1-2$ & - & $\mathrm{p}<0.05$ & $\mathrm{p}<0.01$ & $\mathrm{p}<0.01$ \\
\hline $3-5$ & - & - & $\mathrm{NS}$ & $\mathrm{NS}$ \\
\hline $6-8$ & - & - & - & $\mathrm{NS}$ \\
\hline
\end{tabular}

NS - not significant

Moreover, anti-sperm Ig A titers were the lowest in the group of cows that achieved successful pregnancy following 1-2 Al (Table 5). As in the previous case, we were able to note statistically significant differences between this group and the other two (3-6 and over $6 \mathrm{Al}$ ) groups of animals (Table 5a).

Table 5. Titer of Ig A anti-sperm antibodies in $\mathrm{CM}$ of cows with different numbers of artificial inseminations per calving $(\bar{X} \pm S D)$

\begin{tabular}{|c|c|c|}
\hline Number of Al per calving & $\mathrm{N}$ & Titer of CM anti-sperm Ig A \\
\hline \hline $1-2$ & 24 & $5.66 \pm 1.376$ \\
\hline $3-6$ & 23 & $7.36 \pm 2.597$ \\
\hline over 6 & 13 & $7.40 \pm 1.843$ \\
\hline
\end{tabular}

Table 5a. Statistical significance of differences in titer of CM anti-sperm antibodies between cows with different numbers of artificial inseminations per calving

\begin{tabular}{|c|c|c|c|}
\hline Number of Al per calving & $1-2$ & $3-6$ & over 6 \\
\hline \hline $1-2$ & - & $\mathrm{p}<0.05$ & $\mathrm{p}<0.05$ \\
\hline $3-6$ & - & - & $\mathrm{NS}$ \\
\hline
\end{tabular}

NS - not significant

Finally, the titer of $\lg \mathrm{A}$ anti-sperm antibodies in the younger category of cows (up to 3 years) had the lowest values (Table 6) and there were statistically significant differences between this and the other two groups of animals (Table 6a).

Table 6. Titer of Ig A anti-sperm antibodies in CM of cows of different age ( $\bar{X} \pm S D)$

\begin{tabular}{|c|c|c|}
\hline Age (years) & N & Titer of CM anti-sperm Ig A \\
\hline \hline up to 3 & 15 & $4.76 \pm 1.951$ \\
\hline 3 - 5 & 15 & $7.03 \pm 1.907$ \\
\hline over 5 & 30 & $7.10 \pm 2.299$ \\
\hline
\end{tabular}


Acta Veterinaria (Beograd), Vol. 54, No. 5-6, 337-346, 2004.

Lazarević $\mathrm{M}$ et al. Cutaneous basophil hypersensitivity reaction to phytohemagglutinin in repeat breeder cows

Table 6a. Statistical significances of difference in titer of CM anti-sperm antibodies between cows of different age

\begin{tabular}{|c|c|c|c|}
\hline Age (years) & up to 3 & 3-5 & over 5 \\
\hline \hline up to 3 & - & $\mathrm{p}<0.05$ & $\mathrm{p}<0.05$ \\
\hline $3-5$ & - & - & NS \\
\hline
\end{tabular}

NS - not significant

\section{DISCUSSION}

After years of implementing artificial insemination procedures in cattle breeding it seems that some cows "resist" Al. Since one of the causes of this phenomenon might be an immunological barrier to conception, it was possible to postulate that cows with high general immunoreactivity (high responders) might also react to sperm and extender antigens and become repeat breeders. In order to check this hypothesis we have investigated the relationship one of the tests for estimating general cellular immune reactivity (CBHR) with the reproductive results of cows and titers of anti-sperm Ig A antibodies in their cervical mucus.

We have shown that the intensity of CBHR is significantly lower in cows inseminated 1-2 times compared to that in animals inseminated more than 3 times. However, we found no differences between the other experimental groups and therefore it is our opinion that the degree of reaction is probably more related to the age of the animals. This statement is confirmed by analyzing the same results sorted according to the age of the cows. In this case, we were able to demonstrate that younger cows (up to 3 years of age) also have a significantly lower intensity of skin hypersensitivity reaction to PHA. Moreover, when we sorted data according to the number of inseminations needed for successful pregnancy, we found no differences in CBHR among the experimental groups. It is, then, possible to conclude that there are differences in CBHR related to age.

In our previous study on cows, we showed that mean titers of anti-sperm Ig A antibodies (ASA) were higher in the cervical mucus samples than in sera, indicating that the local immune response is more relevant for the immunological reactivity to sperm and extender antigens (Lazarević et al., 2003). An elevation of sperm-agglutinating antibody titer in the CM and sera of artificially inseminated cows was clearly demonstrated by Jaćević (1998). For that reason we have tried to correlate this parameter with $\mathrm{CBHR}$ and the reproductive results of artificially inseminated cows.

It is well known that ASA may interfere with reproductive processes by impairment of sperm migration through the cervix, uterus and tubes and by blocking adherence of spermatozoa to the surface of the zona pellucida of the oocyte (Schumacher, 1998). The same author stated that serum antibody levels do not reflect properly the immunological situation in secretions of the genital tract especially in females, and that the secretory immunological system may be operational mainly in the cervical compartment of the genital tract. There is strong 
evidence that in humans sperm-mucus interactions can be affected by local ASA, especially of the $\lg$ A class, both under in vitro and in vivo conditions (EggertKruse et al., 1991). However, the significance of ASA in sera of infertile patients was not established, while those in seminal plasma or CM impaired the ability of sperm cells to penetrate CM (Eggert-Kruse et al., 1995).

As documented earlier (Lazarević et al., 2003), the titers of Ig A ASA were significantly lower in the group of animals inseminated once or twice when compared to results obtained for cows inseminated 3 or more times. These cows also had a lower intensity of CBHR. In this study we showed that titers of Ig A ASA in CM were lower in cows that need 1-2 inseminations per calving when compared to the other groups but there were no differences in CBHR. Finally, older cows had higher titers of Ig A ASA in CM and higher CBHR results but these were animals that had been inseminated more times as well.

\title{
ACKNOWLEDGEMENT:
}

This work was supported by a grant from the Ministry of Science, Technology and Development of the Republic of Serbia, No 1998, (Investigations of systemic and local immune reactivity of heifers and cows to sperm antigens and semen extenders)

\author{
Address for correspondence: \\ Prof. Dr Miodrag Lazarević \\ Faculty of veterinary medicine \\ Department of physiology and biochemistry \\ Bul JNA 18, Belgrade \\ Serbia \& Montenegro \\ e-mail: misha@vet.bg.ac.yu
}

\section{REFERENCES}

1. Casida EL, 1961, Present status of the repeat breeder cow problem, J Dairy Sci, 44, 2323-9

2. Eggert Kruse W, Hofsass A, Haury E, Tilgen W, Gerhard I, Runnebaum B, 1991, Relationship between local anti-sperm antibodies and sperm-mucus interactions in vitro and in vivo, Hum Reprod, 6, 2, 267-76.

3. Eggert Kruse W, Rohr G, Bockem-Hellwig S, Huber K, Christmann-Edoga M, Runnebaum B, 1995, Immunological aspects of sub fertility, Int $J$ Androl, 18, Suppl 2, 43-52.

4. Ekkel ED, Kuypers AH, Counotte GHM, Tielen MJM, 1995, The phytohaemagglutinin (PHA) skin test as an indicator of stress-induced changes in immune reactivity in pigs, Vet quart, 17, 143-6.

5. Hogarth JP, 1982, Immunological aspects of mammalian reproduction, Blackie, Glasgow \& London, 50-83.

6. Jaćević V, 1998, Spermaglutinini u krvnom serumu i cervikalnoj sluzi junica i krava sa različitim indeksom osemenjavanja, Magistarska teza, Fakultet veterinarske medicine, Beograd.

7. Jaćević V, Lazarević M, 2000, Antitela protiv spermatozoida i njihov značaj u patogenezi neplodnosti žena, Vojnosanit Pregl, 57, 331-8.

8. Kelley KW, Greenfield RE, Evermann JF, Parish SM, Perrzman LE, 1982. Delayed-type hypersensitivity, contact sensitivity, and phytohemagglutinin skin-test responses of heat- and cold-stressed calves, Am J Vet Res, 43, 775-9.

9. Landers DL, Bronson AD, Pavia SC, Stites PD, 1994, Reproductive immunology, In Stites PD, Terr IA, Parslow GT eds, Medical Immunology, Appletone and Lange, 200-15. 
10. Lazarević $M, 1991$, Ispitivanje imunomodulatornih uloga semene plazme bika u in vitro uslovima, Doktorska disertacija, Fakultet veterinarske medicine, Beograd.

11. Lazarević M, Ejdus Lota, Rosić G, 1992, The influence of bovine seminal plasma, egg yolk extender and their mixture on bovine lymphocyte blastogenesis, Acta veterinaria, 42, 4, 227-36.

12. Lazarević M, Rodić Svetlana, Ostojić Jelena, Jakovljević G, Jovičin M, 2000, Primena indirektne imunofluorescence $u$ određivanju antigenskih karakteristika spermatozoida bika, XIV savetovanje agronoma, veterinara i tehnologa, Aranđelovac, Zbornik naučnih radova, 6, 2, 4019.

13. Lazarević M, Milanović Svetlana, Kirovski Danijela, Milovanović A, 2003, Antisperm antibodies of the Ig A class in the cervical mucus and sera of artificially inseminated cows, Acta veterinaria, 53,5-6, 311-20.

14. Lazarević M, Žikić D, Ušćebrka G, 2000, The influence of long term sound stress on the blood leukocyte count, heterophyl/lymphocyte ratio and cutaneous basophil hypersensitive reaction to phytohemagglutinin in broiler chickens, Acta veterinaria, 50, 2-3, 63-77.

15. McCorkle FJ, Olah I, Glick B, 1980, The morphology of the phytohemagglutinin-induced cell response in the chicken's wattle, Poultry Sci, 59, 616-23.

16. Noel RR, Hjort T, Rumke P, Harper JKM, Vyazov O, 1974, Techniques for detection of iso- and autoantibodies to human spermatozoa, Clin Exp Immunol, 23, 175-99.

17. Park WY, Hunter GA, 1977, Effect of repeated inseminations with egg yolk semen extender on fertility in cattle, J Dairy Sci, 60, 1645-9.

18. Regnier JA, Kelley KW, 1981, Heat- and cold-stress suppresses in vivo and vitro cellular immune responses of chickens, Am J Vet Res, 42, 294-9.

19. Schumacher GF, 1988, Immunology of spermatozoa and cervical mucus, Hum Reprod, 3, 3, 289300.

20. Stedecker MJ, Lukic M, Dvorak A, Leskowitz S, 1977, The cutaneous basophil response to phytohemagglutinin in chickens, $J$ Immunol, 118, 1564-8.

21. The TH, Feltkamp TWE, 1970, Conjugation of fluorescein isothiocyanate to antibodies, I Experiments on the conditions of conjugation, Immunol, 18, 868-73.

22. Sjurin N, Belorusova VR, Fomina VM, 1984, Veterinarnaja virusologija, Kolos, Moskva.

23. Vukotić M, Pavlović M, Stojić V, Petrović S, Kuzmanov D, Predojević M, 1982, Some evidence on immunological resistance of heifers to artificial insemination, In: Proc 4th Int Symp Immunol Reprod, Varna, P 125.

24. Westly HJ, Kelley KWW, 1984, Physiologic concentrations of cortisol suppress cell-mediated immune events in domestic pig. Proceedings of the society for experimental biology and medicine, 177, 156-64.

25. Žikić D, 2000, Uticaj hroničnog zvučnog stresa na imunološki i endokrini sistem pilića hibrida "Hybro", Magistarska teza, FVM Beograd.

\section{TEST KOŽNE PREOSETLJIVOSTI NA FITOHEMAGLUTININ (PHA) KOD KRAVA KOJE POVAĐAJU}

LAZAREVIĆ M, MILOVANOVIĆ A, MILANOVIĆ SVETLANA, KIROVSKI DANIJELA i ILIĆ V

\section{SADRŽAJ}

Cilj ovih ispitivanja je bio da se utvrdi odnos između rezultata testa kožne preosteljivosti na fitohemaglutinin, nekih reproduktivnih pokazatelja i koncentracije antispermatozoalnih antitela lg A klase u cervikalnoj sluzi krava koje se 
veštački osemenjavaju. Test kožne preosetljivosti je izvođen na dan veštačkog osemenjavanja a istog dana su prikupljani i uzorci cervikalne sluzi. Krave su bile podeljene u grupe na osnovu broja ukupnih prethodnih osemenjavanja, prosečnog broja osemenjavanja po graviditetu i na osnovu starosti. Prisustvo antispermatozoalnih antitela je određivano metodom indirektne imunofluorescence korišćenjem spermatozoida suspendovanih u Tris-žumanjčanom razređivaču.

Postignuti rezulati ukazuju da je intenzitet kožne preosetljivosti na PHA manji kod krava koje su osemenjene 1-2 puta kao i kod mlađih jedinki. Intenzitet ove reakcije se nije razlikovao kod krava koje zahtevaju manje ili više pokušaja VO po teljenju. Takođe je dokazano da se titar antispermatozoalnih Ig A antitela u cervikalnoj sluzi povećava sa ukupnim brojem osemenjavanja, brojem osemenjavanja po teljenju i starošću plotkinja. 